\title{
친환경건축물인증 아파트의 친환경계획요소 관리 실태 \\ A Study on the Management of Environmentally Friendly Planning Features in Condominiums with Green Building Certification
}

\author{
경희대학교 주거환경전공 \\ 석사과정 석 희 진 \\ 교 수 홍 형 옥
}

Department of Housing and Interior Design, Kyung Hee University Master Student : Hee-Jean Seok

Professor : Hyung-Ock Hong

\begin{abstract}
$<$ Abstract $>$
The purpose of this paper was to examine the management of Environmentally Friendly Planning Features(EFPF) in condominium with Green Building Certification(GBC). A questionnaire survey was conducted among management office staff and residents on six housing estates in Seoul. The data from 200 respondents were analysed using descriptive statistics and $t$-tests. The main findings were as followings : 1) Most of the staffs considered that garbage collection and recycling, and green spaces were well-managed. 2) The residents indicated that garbage collection and recycling, and green spaces were properly handled, but they failed to recognize these as EFPF. 3) Residency duration was unrelated to the residents' perceptions of the EFPF and their management. In conclusion, neither the residents nor the staff were aware of the GBC system or that their housing estates were built using EFPF. To remedy this, it can be assumed the residents' lack of appreciation of the EFPF can be resolved if they participate in the management of these features. So the residents will need education, and the management staff will require professional training.
\end{abstract}

주제어(Key Words) : 친환경계획요소(environmentally friendly planning features: EFPF), 친환경건축물인증제도 (green building certification: $\mathrm{GBC}$ ), 주택관리(housing management)

Corresponding Author : Hyung-Ock Hong, Department of Housing and Interior Design, Kyung Hee University, 1 Hoegi-dong, Dongdaemun-gu, Seoul, 130-701, Korea Tel: +82-2-961-0259 Fax:+82-2-961-0261 E-mail: hong1215@khu.ac.kr 


\section{I. 서 론}

\section{1. 연구의 배경 및 목적}

1960년대부터 도시의 과밀문제를 해결하기 위해 아파트 가 본격적으로 등장하기 시작하면서 우리나라의 아파트 보 급률은 2008년을 기준으로 70\%(국토해양부, 2009a)를 넘어 서게 되었다. 아파트의 건설이 주택부족이라는 양적인 문제 를 해결하였다는 의의는 있지만 획일화된 주거형태의 공급, 거주 성능과 품질의 하향평준화 등 새로운 문제를 발생시키 는 요인이 되었으며(최영현, 2006) 이에 대한 반성과 대책이 거주 후 평가 연구(김선숙, 양인호, 김광우, 2002; 박영기, 1990) 등에서 나타나고 있다. 이러한 문제는 주로 아파트의 양적 공급이 주요 목표였던 1970-80년대 주거건축물에 대한 평가(박영기, 1990)에서 나타나고 있다. 이러한 문제점들은 1990년대 중반부터 미분양이 속출하자 건설업체들은 미분양 을 줄이기 위한 브랜드의 차별화와 다품종 소량생산 기조를 통해 많이 개선(소경용, 2008)된 것도 사실이다.

현재 국내에서는 지속가능한 사회와 지속가능한 환경의 패러다임(권성실, 오덕성, 김경배, 2006)이 보편화되는 가운 데 친환경에 대한 관심이 고조되어 있고, 정부는 '저탄소 녹 색성장' 이라는 구호아래 그린홈 공급 프로젝트(환경부, 2009) 등을 실시하고 있다. 그 중에서도 2002년부터 국토해 양부와 환경부는 건축물의 친환경성을 평가하는 친환경건축 물인증제도를 도입하여 친환경 공동주택단지의 보급을 지속 적으로 확대하려는 노력이 중요한 전환점이 된 것 또한 사실 이다. 그러나, 친환경인증을 받은 아파트 거주자들의 만족도 연구(신영숙, 조명은, 2006; 유은미, 2008; 이지영, 2005; 임 승남, 2006)는 있으나 친환경건축물 인증에 필요했던 친환경 계획요소들의 관리문제에 대해서는 관심을 덜 기울여 왔다.

아파트건설시 친환경계획요소는 친환경건축물인증을 목 적으로 도입되지만, 거주자의 친환경적 생활과 지속적인 관 리방법을 고려하기 보다는 건설사의 브랜드 가치와 상품가 치를 위한 가시적인 효과를 목적으로 도입되는 요소들도 있 기 때문에 실제 거주시 여러 가지 문제점들이 나타나고 있 다. 거주자의 만족도에 대한 연구에서 보면, 비오톱이 관리 되지 않아 모기가 생기거나 생태천에서는 물이 흐르지 않아 흉물이 되어 있는 등의 문제점들(윤수진, 2009; 정선모, 2005)이 지적되고 있다.

또한 친환경건축물인증제도의 평가항목에 있어서 부문과 범주는 명확하나 세부항목은 '수립 여부', '생태적 가치', '연계여부', '배출저감', '설계의 정도' 등 애매하여 해당아 파트마다 적용방법이 달라 상대적인 비교평가가 이루어질 수 없는 문제점이 있다. 따라서 평가의 세부항목을 비교 평 가하는 것은 인증을 위한 평가사항일 뿐, 이러한 친환경건축
물인증제도를 통해 인증된 아파트에 있어서 실제로 도입한 친환경계획요소가 어떻게 관리되고 있는지를 알아보기 위해 서는 보다 객관적인 기준이 필요하다. 그러한 측면에서 연구 자들이 개발해온 친환경계획요소는 아주 유용하며, 이러한 요소들의 적용에 대해 친환경건축물인증을 받은 아파트의 거주자와 관리자들이 실제로 어떻게 인식하는지 알아볼 필 요가 있다.

따라서, 본 연구의 목적은 서울시 내 친환경인증아파트를 대상으로 그들이 도입한 친환경계획요소에 대한 거주민들의 인식은 어떠하며, 친환경계획요소의 관리에 대해 실무자들 은 어떻게 인식하는지 알아보는 데 있다. 이는 앞으로 거주 자의 사용과 관리지속성을 염두에 둔 친환경건축물인증제도 에 있어서 어떠한 친환경계획요소가 좀 더 고려되어야하는 지 알아낼 수 있을 것으로 사료된다.

\section{2. 연구의 내용 및 연구문제}

친환경건축물인증 아파트 내 친환경계획요소의 관리실태 를 분석하기 위한 연구목적을 가지고 문헌을 통해 선행연구 와 친환경건축물인증제도를 조사함으로써 평가 과정과 범 주, 세부기준을 알아보았다. 관리실태 분석을 위해서는 실제 로 적용된 친환경계획요소들을 정리함으로써 일반아파트와 의 차이점을 알아보고, 친환경계획요소에 대해 관리자와 거 주자가 인지하는 관리 실태를 파악하기 위한 평가도구를 만 들었다. 거주자와 관리자를 대상으로 친환경건축물인증 아 파트의 친환경계획요소에 대한 인식과 관리 실태, 이용실태 를 조사하기 위해 설문조사와 일부 인터뷰를 병행함으로써 친환경건축물인증 아파트의 관리 실태를 분석하여 제언함으 로써 앞으로 인증을 위한 전시효과보다도 관리지속성을 위 해서는 어떠한 요소가 중요한지 친환경계획요소의 적용과 관리방안에 필요한 자료를 제시할 수 있을 것이다.

이상의 연구내용을 알기 위한 구체적인 연구문제는 다음 과 같다.

연구문제 1 거주자와 관리자의 친환경계획요소에 대한 이용 현황과 관리 실태는 어떠한가?

연구문제 2 아파트특성(관리유형, 입주경과년수)에 따라 친 환경계획요소의 관리에 있어서의 차이는 어떠한 가?

연구문제3 거주자와 관리자가 생각하는 효율적인 친환경계 획요소 관리를 위해 필요한 요소는 무엇인가?

\section{3. 연구방법 및 절차}

서울시 내 친환경건축물인증아파트 거주자와 관리자가 인식하는 친환경계획요소의 관리 실태를 분석하기 위한 본 
연구의 방법은 질문지를 이용한 사회조사연구이며 일부 인 터뷰도 병행하였다.

질문지의 내용은 관리자용과 거주자용으로 나누어서 작 성하였다. 관리자용 질문지는 응답자의 일반사항 5 문항, 근 무단지의 일반사항 7 문항, 친환경계획요소의 관리상태 21 문 항, 총 34 문항으로 구성되었다. 거주자용 질문지는 응답자의 일반사항 4 문항, 친환경계획요소의 관리상태 22 문항, 이용 현황 3 문항, 총 29 문항으로 구성되었다. 관리 실태는 선행연 구를 통하여 '에너지 및 자원절약' '주변환경과의 조화', '건강 및 쾌적성' 으로 나누어 세부항목을 추출하여 3점 척도 를 만들었으며, 거주자의 이용현황은 각 세부항목에 대해 이 용하는 빈도수를 순위로 나타낼 수 있도록 설계하였다. 2009년 3월까지 서울시내 친환경건축물인증아파트 인증건 수 80 건 중 가장 밀집되어 있는 지역인 성북구(13건)와 은평 구(20건)를 중심〈그림 1 참조〉으로 6 개의 단지를 선정〈표 1 참조>하여 각 조사대상 단지에 근무하는 관리자와 해당 단지 에 거주하는 만 20 세 이상의 거주자 200 명으로부터 자료를 수집하였다. 6 개 단지를 선정하는 과정은, 최근 인증신청이 많은 2 개구에서 관리유형 3 가지가 모두 포함될 수 있도록 하 기 위해서였으나, 친환경건축물인증 연륜이 짧아 최근 완공 된 아파트이면서 본 인증을 받은 대략 1,000 세대 이내의 아 파트 단지를 선정하기가 어려웠다. 따라서 관리유형을 분석 할 때는 은평구만으로 한정하였다. 그 이유는 성북구는 모두 위탁관리 상태이지만, 은평구는 관리유형 3가지(위탁관리, 자체관리, 사업주체관리)가 모두 있어서 비교가 가능했기 때 문이다. 또한 같은 지역이므로 자연환경, 교통, 교육 등의 환 경이 동일한 거주자들이고, 전혀 다른 여건의 성북구를 배제 함으로써 관리유형을 주요변수로 선정할 수 있다고 사료되 었기 때문이다.

설문조사는 2009년 5월 13일부터 5월 24일까지 시행하였 고, 자료분석을 위한 통계처리는 SPSS 12.0 통계 프로그램 을 이용하였으며 평균, 백분율, 빈도분석, $t$-검증 등을 사용 하여 결과를 도출하였다.

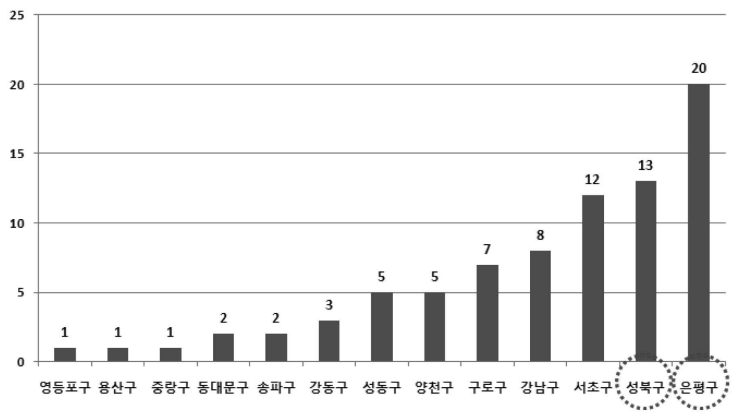

〈그림 1〉서울시내 친환경건축물인증 공동주택단지 현황 출처: 토지주택연구원 친환경건축물인증센터(2010)
〈표 1〉조사대상단지

\begin{tabular}{|c|c|c|c|}
\hline 단지명 & $\begin{array}{c}\text { 정릉 } \\
\text { 현대홈타운 }\end{array}$ & $\begin{array}{l}\text { 종암2차 } \\
\text { 아이파크 }\end{array}$ & $\begin{array}{c}\text { 정릉 } 3 \text { 차 } \\
\text { 힐스테이트 }\end{array}$ \\
\hline 조감도 & & & \\
\hline 지역 & 성북구 & 성북구 & 성북구 \\
\hline 세대수 & 355 & 782 & 522 \\
\hline 관리면적 & 57,494 & 78,755 & 55,614 \\
\hline 동수 & 7 & 15 & 19 \\
\hline 난방방식 & 개별난방 & 개별난방 & 개별난방 \\
\hline 관리방식 & 위탁관리 & 위탁관리 & 위탁관리 \\
\hline 인증일자 & 2004.12 .17 & $\begin{array}{c}2006.3 .17 . \\
\text { (본인증) }\end{array}$ & $\begin{array}{r}2008.4 .7 . \\
\text { (본인증) }\end{array}$ \\
\hline 입주시기 & 2004.12 .21 & 2005.9 .30 & 2008.3 .25 \\
\hline 단지명 & $\begin{array}{c}\text { 은평1지구 } \\
\text { A공구12단지 }\end{array}$ & $\begin{array}{c}\text { 은평1지구 } \\
\text { C공구5단지 }\end{array}$ & $\begin{array}{c}\text { 은평2지구 } \\
\text { A공구1단지 }\end{array}$ \\
\hline 조감도 & & & \\
\hline 지역 & 은평구 & 은평구 & 은평구 \\
\hline 세대수 & 551 & 318 & 947 \\
\hline 관리면적 & 49,407 & 40,453 & 57,603 \\
\hline 동수 & 10 & 9 & 14 \\
\hline 난방방식 & 지역난방 & 지역난방 & 지역난방 \\
\hline 관리방식 & 위탁관리 & 자체관리 & 사업주체관리 \\
\hline 인증일자 & 2006.7 .21 & 2006.8 .2 & 2006.8 .31 \\
\hline 입주시기 & 2008.6 .1 & 2008.6 .1 & 2009.1 \\
\hline
\end{tabular}

\section{II. 이론적 배경}

\section{1. 친환경건축물인증제도의 운영체계}

2002년부터 본격적으로 시행된 친환경건축물인증제도의 목적은 건축물의 자재생산, 설계, 건설, 유지관리, 폐기 등 전 과정을 대상으로 에너지 및 자원의 절약, 오염물질의 배출감 소, 쾌적성, 주변 환경과의 조화 등 환경에 영향을 미치는 요 소에 대한 평가를 통해 건축물의 환경성능을 인증함으로써 친환경건축물 건설을 유도하고 촉진시키고자 함(국토해양 부, 환경부, 2006)에 있다. 건축물은 철강 등 기초소재, 수도, 단열재 등 건축기자재, 전기 및 기계설비 뿐 아니라 조경 등 연관 산업에 대한 파급효과가 큰 분야로서 건설, 사용, 폐기 과정에서 환경영향이 크다. 그런데, 우리나라는 건축물의 신 축과 재건축이 활발하고, 기후변화문제와 관련하여 환경친 화성 증진 방안에 대한 국제적 논의가 활발하게 진행됨에 따 라 친환경건축물인증제도의 필요성(이도형, 2003)이 증대된 점도 이러한 제도의 시행을 불가피하게 한 요인이라고 볼 수 있다. 
〈표 2〉분야별 심사기준(공동주택)

\begin{tabular}{|c|c|c|c|c|}
\hline 구분 & 부문 & 범주 & 세부항목 & 배점 \\
\hline \multirow{33}{*}{ 평가항목 } & \multirow{5}{*}{ 토지이용 } & 생태적 가치 & 기존대지의 생태학적 가치 & 2 \\
\hline & & 토지이용 & 용적율 & 6 \\
\hline & & \multirow{3}{*}{ 거주환경의 조성 } & 커뮤니티센터 및 시설계획 여부 & 3 \\
\hline & & & 단지 내 보행자 전용도로 조성 여부 & 3 \\
\hline & & & 외부보행자 전용도로 네트워크 연계여부 & 1 \\
\hline & \multirow{3}{*}{ 교통 } & \multirow{3}{*}{ 교통부하저감 } & 대중교통에의 근접성 & 2 \\
\hline & & & 단지 내 자전거 보관소 및 자전거도로 설치 여부 & 2 \\
\hline & & & 도시중심 및 지역중심과 단지중심간의 거리 & 2 \\
\hline & 에너지 & 에너지 소비 & 에너지 소비량 & 12 \\
\hline & \multirow{6}{*}{ 재료 및 자원 } & \multirow{2}{*}{ 자원절약 } & 라이프사이클 변화를 고려한 평면개발 & 3 \\
\hline & & & 환경친화적(공업화) 공법 및 신기술 적용 & 3 \\
\hline & & 폐기물 최소화 & 생활용 가구재 사용억제대책의 타당성 & 1 \\
\hline & & \multirow{2}{*}{ 생활 폐기물 } & 재활용 생활폐기물 분리수거 & 2 \\
\hline & & & 음식물 쓰레기 저감 & 2 \\
\hline & & 자원 재활용 & 유효자원 재활용을 위한 친환경인증제품 사용 여부 & 3 \\
\hline & \multirow{3}{*}{ 수자원 } & 수순환 체계구축 & 우수부하 절감대책의 타당성 & 3 \\
\hline & & \multirow{2}{*}{ 수자원 절약 } & 생활용 상수 절감 대책의 타당성 & 4 \\
\hline & & & 우수이용 & 2 \\
\hline & 환경오염 & 지구온난화 방지 & 이산화탄소 배출 저감 & 3 \\
\hline & \multirow{2}{*}{ 유지관리 } & 효율적인 건물관리 & 운영/유지관리 문서 및 지침 제공의 타당성 & 3 \\
\hline & & 효율적인 세대관리 & 사용자 매뉴얼 제공 & 3 \\
\hline & \multirow{6}{*}{ 생태환경 } & \multirow{3}{*}{ 대지 내 녹지 공간 조성 } & 연계된 녹지축 조성 & 2 \\
\hline & & & 녹지 공간율 & 5 \\
\hline & & & 생태환경을 고려한 인공 환경 녹화 기법 적용여부 & 4 \\
\hline & & \multirow{2}{*}{ 생물서식공간조성 } & 수생 비오톱 조성 & 3 \\
\hline & & & 육생 비오톱 조성 & 3 \\
\hline & & 자연자원의 활용 & 표토재활용율 & 1 \\
\hline & \multirow{5}{*}{ 실내환경 } & \multirow{2}{*}{ 공기환경 } & 각종 유해물질 저감자재의 사용 & 6 \\
\hline & & & 환기 설계의 정도 & 3 \\
\hline & & 온열환경 & 각 실별 자동 온도 조절 장치 채택 여부 & 2 \\
\hline & & \multirow{2}{*}{ 음환경 } & 층간 경계 바닥 충격음 차단성능 수준 & 4 \\
\hline & & & 세대간 경계벽 차음성능 수준 & 3 \\
\hline & \multirow{4}{*}{ 토지이용 } & & 합 계 & 100 \\
\hline \multirow{14}{*}{ 가산항목 } & & 생태가치 & 기존 자연자원 보존율 & 3 \\
\hline & & 토지이용 & 체계적 상위계획 수립 여부 & 2 \\
\hline & & 인접대지 영향 & 일조권 간섭방지 대책의 타당성 & 2 \\
\hline & 교통 & 교통부하저감 & 초고속정보통신설비의 수준 & 2 \\
\hline & 에너지 & 에너지 절약 & 신 · 재생에너지 이용 & 3 \\
\hline & \multirow{2}{*}{ 재료 및자원 } & \multirow{2}{*}{ 자원활용 } & 기존건축물의 재사용(주요구조부)으로 재료 및 자원 절약 & 7 \\
\hline & & & 기존건축물의 재사용(비내력벽)으로 재료 및 자원 절약 & 2 \\
\hline & 수자원 & 수자원 절약 & 중수도 설치 & 4 \\
\hline & 유지관리 & 체계적인 현장관리 & 환경을 고려한 현장관리계획의 합리성 & 1 \\
\hline & 생태환경 & 자연자원의 활용 & 표토재활용율 & 1 \\
\hline & \multirow{4}{*}{ 실내환경 } & 음환경 & 단지 내 음환경 & 3 \\
\hline & & 빛환경 & 세대 내 일조 확보율 & 4 \\
\hline & & 노약자에 대한배려 & 노약자, 장애자 배려의 타당성 & 2 \\
\hline & & & 합 계 & 36 \\
\hline
\end{tabular}

출처 : 국토해양부, 환경부(2006). pp. 17-19 


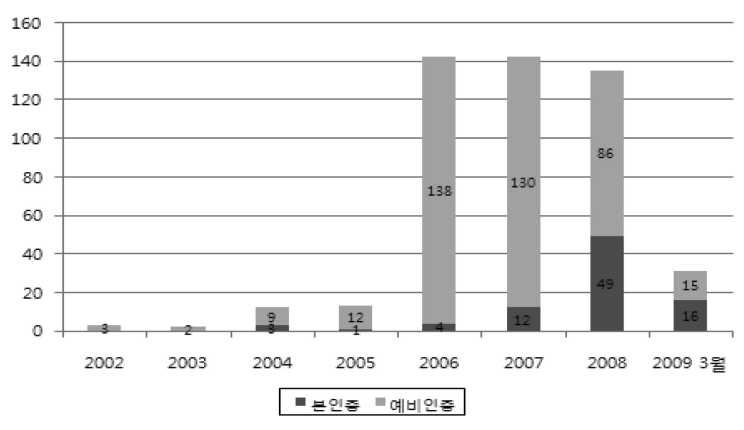

〈그림 2〉 친환경건축물인증 공동주택단지 현황 출처: 토지주택연구원 친환경건축물인증센터(2010)

그동안 강조되어 온 필요성과 친환경건축물인증제도의 운영체계의 정착으로 인해 점차 그 인식이 확대되어 왔으며, 현재는 분양을 목적으로 하는 아파트단지의 건설에 참여하 는 시행사나 건설사가 앞 다투어 도입을 하고 있고, 이를 해 당단지의 홍보에 적극 활용하고 있는 추세이다. 현재 친환경 건축물인증제도의 운영체계는 다음과 같다.

(1) 친환경건축물을 건설하는 건축주는 건축물 환경성능 자 체평가서와 함께 인증기관에 인증신청을 한다.

(2) 운영기관(국토해양부 - 환경부)으로부터 인증기관 지정을 받은 인증기관은 인증심사단을 구성하여 서류심사 및 현 장실사를 통하여 인증평가결과를 심의하여 최종심의 결 과를 운영기관에 보고한다.

(3) 인증기관은 건축주에게 인증을 부여하며 건축주는 인증 받은 것을 홍보할 수 있다.

인증신청 및 방법은 예비인증의 경우에는 설계 시에 예비 인증신청을 할 수 있으며, 사용승인을 취득한 건축물은 언제 나 신청이 가능하다. 예비인증을 발급받아 분양광고에 활용 할 수 있으며, 예비인증 이후 본인증 이전에 건축물과 관련 변동사항(소유주, 인증범위, 환경성능, 평가내용 등) 발생 시 사후관리 심사를 받아야 한다.

운영기관(국토해양부 · 환경부)으로부터 지정을 받은 인 증기관은 토지주택연구원, 한국에너지기술연구원, 크레비즈 인증원으로써 심사기준으로 토지이용 및 교통, 에너지자원 및 환경부하, 생태환경, 실내환경의 4 개 유형 총 44 개 항목 중 31 개의 평가항목 100 점과 13 개의 가산항목 36 점, 총 136 점 만점으로 심사하여 평가한다. 100점 만점 중에서 65 점 이 상일 경우 우수등급을 획득하게 되며, 85점 이상일 경우 최 우수 등급을 획득하게 된다.

친환경건축물인증 우수, 최우수 등급을 획득한 공동주택 (업무용 및 주거복합건물, 학교를 제외)의 인증건수는 2002 년 3건, 2003년 2건, 2004년 11건, 2005년 13건, 2006년 142 건, 2007년 55건, 2008년 135건, 2009년 3월 기준 31건으로
현재까지 총 481 건의 친환경건축물인증아파트가 있는 것으 로 나타났다〈그림 1 참조〉.

주목할 점은 2006년 인증건수가 전년도에 비해 무려 11배 이상이 증가하였다는 사실이다. 뿐만 아니라 분양 시 홍보를 위한 필수전략으로 예비인증을 광고할 수 있기 때문에 필요 에 따라 예비인증 건수도 괄목할 정도로 늘어나고 있다<그림 2 참조>. 또 한 가지 이유는 2006년 2월 정부가 주택공급에 관한 규칙을 개정하여 친환경건축물인증으로 인한 분양가 가산비용에 기본형 건축비의 $3 \%$ 에 해당하는 비용을 추가보 전 받도록 하는 인센티브규정을 마련했기 때문으로 볼 수 있 다. 기본형 건축비를 적용받는 공공택지 내 대규모 단지가 친환경건축물인증을 받으면 많은 비용을 분양가로 보전받을 수 있는 셈(유은미, 2008)으로서 시행사와 건설회사들이 앞 다투어 인증을 받으려고 노력하고 있는 점이 한 몫을 하고 있다고 할 수 있다. 그러나 인증을 받고 난후 사업주체관리 가 진행되는 기간은 친환경계획요소들이 목적에 맞게 관리 되지만, 그 이후 관리유형이 위탁관리나 자체관리로 바뀌고 나면 비용문제와 거주자와 관리자의 인식부족으로 관리부실 문제가 발생할 수 있음을 주목할 필요가 있다.

\section{2. 친환경계획요소의 내용}

친환경계획요소는 친환경건축물인증제도의 목표를 만족 시키기 위하여 적용되는 구체적 요소로서 건축물의 친환경 성을 측정하는 기준을 제공한다고 할 수 있다. 이러한 친환

〈표 3〉 친환경건축물인증제도의 계획목표별 친환경계획요소

\begin{tabular}{|c|c|}
\hline 계획목표 & 세부계획요소 \\
\hline $\begin{array}{l}\text { 에너지 및 } \\
\text { 자원절약 }\end{array}$ & $\begin{array}{l}\text { 쓰레기 분리수거 및 재활용을 위한 공간 } \\
\text { ·열완충공간 조성(방풍실) } \\
\text { · 친환경주차장 배치(집중형, 지하형) } \\
\text { · 단지내 자전거보관소 및 자전거도로설치 } \\
\text { · 에너지절약형 난방설비 } \\
\text { · 고효율 에너지 절약형기기의 사용 } \\
\text { · 절수형 설비기기의 채용 } \\
\text { · 우수이용 및 중수도 설치 } \\
\text { · 음식물 쓰레기 감량화·고형화 장치의 적용 }\end{array}$ \\
\hline $\begin{array}{c}\text { 주변환경과의 } \\
\text { 조화 }\end{array}$ & $\begin{array}{l}\cdot \text { 오픈스페이스 } \\
\text { · 녹지공간과의 접근성 및 연계 } \\
\text { · 기존지형 활용 } \\
\text { · 단지순환 실개천 및 분수 조성 } \\
\text { · 인공녹화 조성 } \\
\text { · 육생 및 수생 비오톱 조성 } \\
\text { · 생태학습원 } \\
\text { · 옥상 또는 단지 내 공동텃밭이나 채원조성 }\end{array}$ \\
\hline $\begin{array}{c}\text { 건강 및 쾌적성 } \\
\text { 향상 }\end{array}$ & $\begin{array}{l}\text { · 실내정원 및 발코니 녹화 } \\
\text { · 단지 내 다양한 휴게공간 조성 } \\
\text { · 거주공간의 환기계획 } \\
\text { · 제어장치(실별 온도조절및 조명제어장치) } \\
\text { · 정보통신 및 첨단 생활서비스 채택 }\end{array}$ \\
\hline
\end{tabular}

출처 : 최유리(2007).pp. 30-31에서 재인용 
〈표 4〉 친환경계획요소 평가에 대한 선행연구

\begin{tabular}{|c|c|c|c|}
\hline 저자 & 년도 & 연구제목 & 조사대상/연구내용 \\
\hline 이도형 & 2003 & $\begin{array}{l}\text { 친환경 공동주택의 특성분석 및 인식에 } \\
\text { 관한 연구 }\end{array}$ & $\begin{array}{l}\text { - 친환경우수단지 거주자와 건축전문가 } \\
\text { - 친환경건축물에 대한 인식을 비교· 분석 }\end{array}$ \\
\hline 이지영 & 2005 & $\begin{array}{l}\text { 거주자의 생태적 환경 및 친환경주거 } \\
\text { 계획요소 인식연구 }\end{array}$ & $\begin{array}{l}\text { - 거주자 } \\
\text { - 생태적 환경인식과 친환경계획요소에 대한 중요도 분석 } \\
\text { - 거주자의 친환경계획요소 요구사항 }\end{array}$ \\
\hline $\begin{array}{l}\text { 조명은 } \\
\text { 신영숙 }\end{array}$ & 2006 & $\begin{array}{l}\text { 친환경아파트단지 거주자들의 친환경계획 } \\
\text { 요소에 대한 인식에 관한 연구 }\end{array}$ & $\begin{array}{l}\text { - 친환경주거단지 거주자 } \\
\text { - 외부 및 실내환경의 친환경성에 대한 인지도 및 만족도, } \\
\text { 친환경계획요소 이용도와 만족도 및 선호사항 }\end{array}$ \\
\hline 임승남 & 2006 & $\begin{array}{l}\text { 주거단지 친환경계획요소에 대한 만족도 및 } \\
\text { 중요도 평가에 관한 연구 }\end{array}$ & $\begin{array}{l}\text {-친환경인증 주거단지 거주자 } \\
\text { - 친황주거단지의 외부공간평가지표 } \\
\text { - 친환경주거단지 외부공간조성 계획요소의 방향 제시 }\end{array}$ \\
\hline 최유리 & 2007 & $\begin{array}{l}\text { 브랜드아파트에 적용된 친환경적 계획 } \\
\text { 요소에 관한 사례연구 }\end{array}$ & $\begin{array}{l}\text { - 서울시에 위치한 브랜드 아파트 } \\
\text { - 친환경계회요오 정용 평가 } \\
\text { - 친환경적 주거계획의 경향 분석 }\end{array}$ \\
\hline 유은미 & 2008 & $\begin{array}{l}\text { 친환경건축물인증아파트단지 거주자의 } \\
\text { 주거환경만족도 }\end{array}$ & $\begin{array}{l}\text { - 친환경건축물 본 인증을 횓득한 울산아파트 거주자 } \\
\text { - 친환경계획요소에 대한 인식과 만족도 }\end{array}$ \\
\hline $\begin{array}{l}\text { 정희석 } \\
\text { 정동훈 } \\
\text { 제해성 }\end{array}$ & 2009 & $\begin{array}{l}\text { 초고층 주거복합건축물 옥외공간의 } \\
\text { 친환경계획요소에 관한 연구 }\end{array}$ & $\begin{array}{l}\text { - 초고층주거복합건축물 옥외공간 사용자 } \\
\text { - 초고층 주거본합건축물 옥외공간의 친환경계획요소 } \\
\text { 현황 ㅁㅣㅣ 문제점 } \\
\text { - 옥외공간 제안 및 개선사항 }\end{array}$ \\
\hline
\end{tabular}

경계획요소의 내용은 친환경건축물인증 주거단지 내에 계획 된 요소를 구분 짓거나 통합된 기준을 작성하기 위하여 작성 된다. 친환경건축물인증제도의 평가항목과 가산항목 32 개 범주에 따른 45 개 세부항목을 달성하기 위한 계획목표를 분 석하면, 크게 에너지 및 자원절약, 주변환경과의 조화, 건강 및 쾌적성 향상의 3 가지 부문으로 요약 정리될 수 있다.

또한 이러한 계획목표들이 실제로 적용될 때 나타나는 계 획요소들을 친환경계획요소의 세부계획요소 항목으로 정리 할 수 있는데, 다수의 연구에서 활용되는 기준들〈표3 참조〉 을 보면, 대상 단지에 따라 다소 가감이 있거나 용어의 수정 이 있을 뿐 대동소이하다. 그러나 이는 구체적 계획요소이므 로 친환경건축물인증 아파트의 인증을 위한 계획목표가 실 제 어떻게 인식되고 관리되고 있는지 알아보기 위한 평가항 목으로 훨씬 유용하다.

\section{3. 친환경계획요소 평가에 대한 선행연구}

2002년 친환경건축물인증제도가 도입되면서 친환경공동 주택에 대한 연구는 꾸준히 지속되어 왔다. 연구는 크게 인 증받은 공동주택단지의 친환경계획요소 현황분석과 거주자 들이 인식하는 친환경계획요소의 만족도분석으로 나눌 수 있다.

초기에는 친환경건축물인증을 받은 단지의 친환경계획요 소 인식에 관한 연구가 진행되었으며, 최근에는 브랜드아파 트 및 초고층주상복합건축물을 대상으로 전개되고 있다. 대 표적인 연구를 년도 별로 분류해보면 〈표 4〉와 같으며, 거주 자와 관리자를 중심으로 친환경계획요소의 관리실태를 분석
한 연구는 거의 없음을 알 수 있다.

정부의 녹색성장기조에 맞추어 건설회사의 건설패러다임 의 변화에 기인하여 친환경계획요소 도입의 선호요소가 달 라진다고 볼 수도 있겠지만, 분양호조를 기대하는 심리를 배 제할 수 없기 때문에 가시적으로 도입되는 요소들도 많다. 따라서 입주 후 사업주체 관리기간은 관리가 잘되지만 자체 관리 혹은 위탁관리를 선택해야하는 이후의 관리 실태는 많 은 문제점들이 있을 수 있으며, 이에 대한 입주자와 관리자 의 인식과 현황은 친환경계획요소의 관리지속성을 위해 중 요한 문제가 아닐 수 없다. 이는 또한 친환경건축물인증의 실효성을 위해서도 중요한 문제라고 할 수 있다.

\section{III. 결과 해석}

\section{1. 조사대상자의 일반적 특성}

\section{1) 거주자의 일반적 특성}

전체 조사대상 거주자는 성북구와 은평구 각각 $50.0 \%$ 로 유의표집 하였다. 거주자 200 명에 대한 설문조사는 관리자 인터뷰를 먼저하고 허락을 받은 후에 실시하였다. 성별은 여 성 152 명(76.0\%), 남성 48 명(24.0\%)으로 여성이 더 많았다. 연령은 30세 이상 40 세 미만이 103명(51.5\%)으로 가장 많았 고 40세 이상 50세 미만이 77명(38.5\%)으로 나타났다.

조사대상자가 거주하는 단지로는 성북구의 경우 현대홈 타운이 25 명(12.5\%), 힐스테이트 3차가 41명(20.5\%), 아이파 크 2 차가 34 명(17.7\%)이다. 은평구는 은평뉴타운 1지구가 
〈표 5〉거주자의 일반적 특성

\begin{tabular}{|c|c|c|}
\hline & 항목 & $f(\%)$ \\
\hline \multirow{3}{*}{ 성별 } & 남 & $48(24.0)$ \\
\hline & 여 & $152(76.0)$ \\
\hline & 계 & $200(100.0)$ \\
\hline \multirow{5}{*}{ 연령 } & 20대 & $4(2.0)$ \\
\hline & 30대 & $103(51.5)$ \\
\hline & 40대 & $77(38.5)$ \\
\hline & 50대 & $16(8.0)$ \\
\hline & 계 & $200(100.0)$ \\
\hline \multirow{3}{*}{ 거주 지역 } & 성북구 & $100(50.0)$ \\
\hline & 은평구 & $100(50.0)$ \\
\hline & 계 & $200(100.0)$ \\
\hline \multirow{6}{*}{ 거주 단지 } & 성북현대홈타운 & $25(12.5)$ \\
\hline & 성북힐스테이트 3 차 & $41(20.5)$ \\
\hline & 성북아이파크2차 & $34(17.0)$ \\
\hline & 은평1지구 & $70(35.0)$ \\
\hline & 은평2지구 & $30(15.0)$ \\
\hline & 계 & $200(100.0)$ \\
\hline \multirow{4}{*}{ 입주 경과 } & 1년미만 & $84(42.0)$ \\
\hline & 1년이상 3년미만 & $88(44.0)$ \\
\hline & 3년이상 & $28(14.0)$ \\
\hline & 계 & $200(100.0)$ \\
\hline
\end{tabular}

70명(35.0\%), 은평뉴타운 2지구가 30명(15.0\%) 표집되었다. 거주자의 입주경과년수는 1년 미만이 84명(42.0\%), 1년 이상 3 년 미만이 88명(44.0\%), 3년 이상이 28명(14.05)으로 나타 났다〈표 5 참조〉. 3 년 미만의 친환경인증아파트 거주자가 많 은 이유는 2006년 정부의 건축비 인센티브규정으로 인하여 인증을 받은 아파트가 급속히 증가하였기 때문이라고 볼 수 있다.

\section{2) 관리자의 일반적 특성}

각 단지 관리자 중 과장 급 이상의 성별은 모두 남성이었으 며 경리업무 등은 여성이 맡고 있었다. 연령은 30 대에서 40 대 후반으로 나타났으며, 학력은 고등학교 졸업 이하보다는 대학 교 졸업 이상이 많았다. 친환경인증아파트에서 근무한 총 경 력은 현 근무단지를 포함하여 1년에서 5년까지 다양하지만 총 근무 단지 수는 대개 2 단지 이내〈표 6 참조〉로 나타났다.

3) 조사대상단지의 친환경계획요소 적용 개요

조사대상단지는 친환경건축물인증을 받은 단지로서 인근 타 단지에 비해서 친환경적 계획요소들이 많이 적용되었다. 주변 환경과의 연계성, 식재 및 입면 녹화, 자연채광 및 통풍 을 유도한 설계, 오픈스페이스, 친수 공간 등이 조성되어 있

〈표 6〉 관리자의 일반적 특성

\begin{tabular}{ccccccc}
\hline 항목 & $\begin{array}{c}\text { 정릉 } \\
\text { 현대홈타운 }\end{array}$ & $\begin{array}{c}\text { 종암 2차 } \\
\text { 아이파크 }\end{array}$ & $\begin{array}{c}\text { 정릉 3차 } \\
\text { 힐스테이트 }\end{array}$ & $\begin{array}{c}\text { 은평1지구A } \\
\text { 공구12단지 }\end{array}$ & $\begin{array}{c}\text { 은평1지구C } \\
\text { 공구5단지 }\end{array}$ & $\begin{array}{c}\text { 은평2지구A } \\
\text { 공구1단지 }\end{array}$ \\
\hline 성별 & 남성 & 여성 & 여성 & 남성 & 남성 & 남성 \\
\hline 연령 & 40 세 & 38세 & 43세 & 48 세 & 45 세 & 47 세 \\
\hline 직위 & 관리소장 & 대리 & 경리업무 & 과장 & 관리소장 & 과장 \\
\hline 최종학력 & 대학교졸업 이상 & 고등학교졸업 이하 & 대학교졸업 이상 & 고등학교졸업 이하 & 대학교졸업 이상 & 대학교졸업 이상 \\
\hline $\begin{array}{c}\text { 친환경인증 아파트 } \\
\text { 근무 총 경력 }\end{array}$ & 1년 & 5년 & 5년 & 1년 & 1년 6개월 & 2 \\
\hline $\begin{array}{c}\text { 친환경인증 아파트 } \\
\text { 총 근무 단지 수 }\end{array}$ & 1개 단지 & 1개 단지 & 2개 단지 & 1개 단지 & 2개 단지 & 2 2개 단지 \\
\hline
\end{tabular}

〈표 7〉 은평뉴타운 지구의 친환경계획요소

\begin{tabular}{ccccccc}
\hline 항목 & 기존공원과의 연계 & 친수공간 조성 & 단지녹화 & 자연채광 및 통풍유도 & 자원회수시설 & 태양광 발전설비 \\
\hline & & & & &
\end{tabular}

출처: 은평뉴타운 홈페이지(newtown.i-sh.co.kr) 
으며 특히, 은평 뉴타운 지구에는 수송관로를 통해서 음식물 쓰레기를 수거하여 단지에 쾌적함을 제공하며 지역난방으로 활용 가능하도록 도입된 자원회수시설과 태양광발전설비를 볼 수 있었다〈표 7 참조〉.

\section{2. 친환경계획요소의 이용현황과 관리 실태}

\section{1) 거주자의 친환경계획요소 이용현황}

친환경인증제도의 계획목표에 따라 크게 에너지 및 자원 절약, 외부공간, 건강 및 쾌적성 부문으로 나누어 친환경계 획요소의 이용현황 빈도수를 산출하였다〈그림 3 참조〉.

'에너지 및 자원절약 부문' 에서 거주자의 이용현황을 보 면, 1순위로는 전체거주자 200명 중 65 명이 쓰레기 분리수거 및 재활용 공간을 가장 많이 이용하고 있다고 응답하였고, 다음으로는 자전거 보관소 및 도로(58명)를 이용하는 것으로 나타났다. 2순위도 1순위와 마찬가지로 쓰레기분리수거 및 재활용공간(62명)과 자전거 보관소 및 도로(54명)를 많이 이 용하는 것을 알 수 있다.

'외부공간 부문' 에서 거주자의 이용실태를 보면 1순위로 는 전체거주자 200 명 중 74 명이 오픈스페이스를 가장 많이 이용하고 있다고 응답하였고, 다음으로는 녹지공간(64명)을 이용하는 것으로 나타났다. 그러나 2순위로는 녹지공간(71 명)을 가장 많이 이용하였고, 다음으로 실개천 및 분수(47명) 를 이용하는 것을 알 수 있다. 따라서 2순위까지 누적빈도를 보면 녹지공간이 135 명으로 가장 많았고 다음으로 오픈스페 이스 107 명, 실개천 및 분수 79 명, 생태학습원 52 명 순으로 나타났다.

'건강 및 쾌적성부문' 에서 거주자의 이용실태를 보면, 1 순위로는 전체거주자 200 명 중 110 명이 실내정원 및 발코니

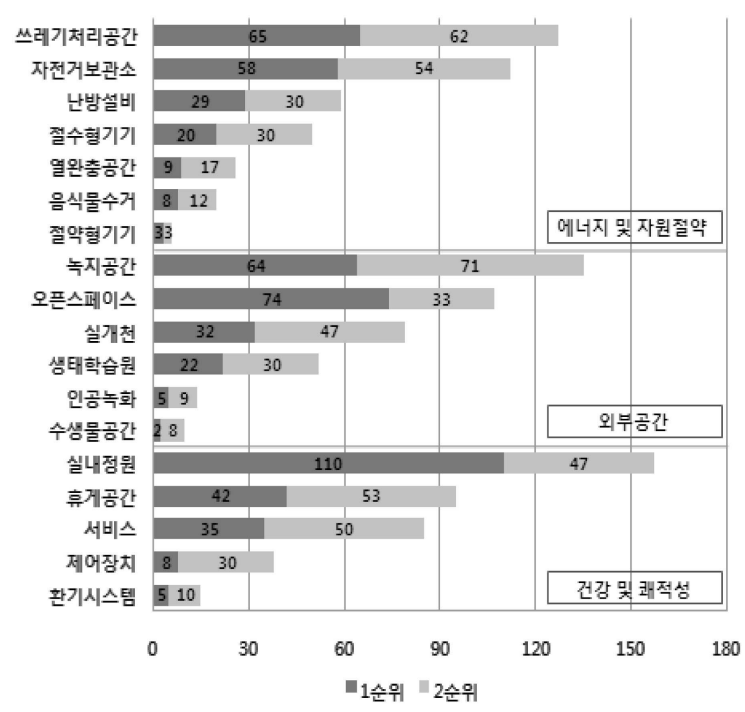

〈그림 3〉 거주자의 친환경계획요소 이용현황
를 가장 많이 이용한다고 하였고, 다음으로 다양한 휴게공간 (42명)을 이용하는 것으로 나타났다. 2순위로는 다양한 휴게 공간 (53명), 통신 및 생활서비스(50명), 실내정원 및 발코니 (47명) 순인 것을 알 수 있다. 2순위까지 누적빈도를 보면, 실 내정원이 157 명으로 가장 많았고 휴게공간 95 명, 통신 및 생 활서비스 85 명, 온도조절·조명제어장치 38 명, 환기시스템 15 명 순으로 나타났다. 이로써 쓰레기 분리수거 및 재활용, 오픈스페이스, 실내정원 및 발코니 등 거주자의 삶에 직접적 인 관련이 있으며 인식하기 쉬운 친환경계획요소들을 더 많 이 이용하는 것을 알 수 있으며, 이용횟수에 따라 중요도도 다른 것으로 분석되었다.

2) 거주자가 인식하는 친환경계획요소의 관리실태

친환경인증제도의 계획목표에 따라 크게 에너지 및 자원 절약, 외부공간, 건강 및 쾌적성부문으로 나누어 3점 척도(잘 되고 있다, 보통이다, 잘 되지 않고 있다)로 응답한 점수의 평균을 분석하였다〈표 8 참조〉.

'에너지 및 자원절약부문' 에는 '쓰레기 분리수거 및 재활 용을 위한 공간 이 평균 2.69로 관리가 가장 잘 되고 있다고 인식하는 항목으로 나타났다. 은평뉴타운에 있는 자원회수 시설은 기존 수거방식의 문제점인 악취발생 및 수거차량소 음, 쓰레기적치물 등으로 인한 도시미관저해를 방지하는 최 신설비시설이다. 이 쓰레기 수송관로 시스템은 가정에서 발 생한 생활쓰레기를 입주민이 직접 아파트 1층에 설치된 투입 구로 넣으면 지하에 매설된 수송관로로 이송하여 분리한 후 소각하기 때문에 위생적이다. 조사대상자의 $50 \%$ 를 차지하는 은평뉴타운의 거주자들 대부분이 이 설비에 만족하기 때문 에 쓰레기 분리수거 및 재활용을 위한 공간 항목의 평균이 높게 나온 것으로 보인다.

‘절수형 설비기기’, ‘우수이용 및 중수도', ‘음식물쓰레기 감량화 · 고형화 장치' 항목의 경우에는 몇몇 거주자와 인터 뷰 결과 이러한 시설이 있는지 조차 거주자들이 잘 인식하지 못하는 편이었으므로 사실상 '잘 모르겠다' 라고 응답한 결 과라고 볼 수 있다.

'외부공간부문' 의 경우 '녹지공간' 에 대한 관리 인식정도 가 2.53으로 가장 높았으며, 다음으로 '오픈스페이스(2.48)' 가 높게 나타났다. '실개천 및 분수(1.57)'와 '수생물공간 (1.60)' 항목은 전체평균 2.06에 미치지 못했는데 현재 물이 마른 채로 방치되어 있는 실개천이 관리인식정도에 큰 영향 을 미친 것으로 보인다. 은평1지구에는 단지를 순환하는 방 식의 실개천이 존재하지만 물이 쉽게 마르는 건천이며, 물을 끌어오기 어려운 위치에 있어 비용이 많이 드는 등 주위환경 이 뒷받침해주지 않아서 현재 방치되어 있다. 한편, ‘공동텃 밭'을 적용하고 있는 단지가 없어서 그에 대한 결과는 얻지 
〈표 8〉거주자 및 관리자가 인식하는 친환경계획요소의 관리실 태 인식정도 비교

\begin{tabular}{|c|c|c|c|}
\hline \multirow{2}{*}{ 부문 } & \multirow{2}{*}{ 항목 } & \multicolumn{2}{|c|}{ 평균 } \\
\hline & & 거주자 & 관리자 \\
\hline \multirow{9}{*}{$\begin{array}{c}\text { 에너지 } \\
\text { 및 } \\
\text { 자원절약 }\end{array}$} & $\begin{array}{l}\text { 쓰레기 분리수거 및 } \\
\text { 재활용을 위한 공간 }\end{array}$ & 2.69 & 2.83 \\
\hline & $\begin{array}{l}\text { 단지 내 자전거 } \\
\text { 보관소 및 도로 }\end{array}$ & 2.54 & 2.33 \\
\hline & 에너지절약형 난방설비 & 2.30 & 2.00 \\
\hline & 열 완충 공간 & 2.24 & 1.33 \\
\hline & $\begin{array}{l}\text { 고효율 에너지 } \\
\text { 절약형기기 }\end{array}$ & 2.21 & 2.33 \\
\hline & 절수형 설비기기 & 1.97 & 2.83 \\
\hline & 우수이용 및 중수도 & 1.70 & 2.17 \\
\hline & $\begin{array}{l}\text { 음식물쓰레기 } \\
\text { 감량화· 고형화 장치 }\end{array}$ & 1.53 & 1.00 \\
\hline & 소 계 & 2.14 & 2.10 \\
\hline \multirow{8}{*}{ 외부공간 } & 녹지공간 & 2.53 & 2.50 \\
\hline & 오픈스페이스 & 2.48 & 2.17 \\
\hline & 생태학습원 & 2.10 & 1.83 \\
\hline & 인공녹화 & 2.08 & 2.50 \\
\hline & 수생물공간 & 1.60 & 0.83 \\
\hline & 실개천 및 분수 & 1.57 & 2.00 \\
\hline & 공동텃밭 & $\cdot$ & . \\
\hline & 소 계 & 2.06 & 1.97 \\
\hline \multirow{6}{*}{$\begin{array}{c}\text { 건강 } \\
\text { 및 } \\
\text { 쾌적성 }\end{array}$} & $\begin{array}{l}\text { 실내정원 및 발코니의 } \\
\text { 쾌적성 }\end{array}$ & 2.59 & 2.00 \\
\hline & $\begin{array}{l}\text { 온도조절 및 조명 } \\
\text { 제어장치 }\end{array}$ & 2.45 & 2.83 \\
\hline & $\begin{array}{l}\text { 통신 및 생활서비스의 } \\
\text { 편리한 이용 }\end{array}$ & 2.37 & 2.67 \\
\hline & 다양한 휴게공간 조성 & 2.35 & 2.33 \\
\hline & $\begin{array}{l}\text { 거주공간의 환기계획 } \\
\text { (환기시스템) }\end{array}$ & 2.32 & 2.00 \\
\hline & 소 계 & 2.42 & 2.37 \\
\hline
\end{tabular}

주. 3 =잘되고있다, 2 =보통이다, 1 =잘 되지 않고 있다

못하였다.

관리자에게 개방형 질문을 한 결과, 분양 후 1 년은 사업주 체관리로 인해 실개천에 물이 흘렀지만 위탁관리로 전환하 면서 현재 비용문제로 거주자와 사업주체가 대립되어 있는 상황임을 알 수 있었다. 또한 거주자들의 개방형 응답을 통 해서도 실개천 곳곳에 조금씩 고인 물로 인해 모기 등의 벌 레가 생기고, 주변경관과 어울리지 않아서 불만이 많은 것을 알 수 있었다.

'건강 및 쾌적성 부문' 의 관리 실태는 전체적으로 보통이 상으로 나타났다. '실내정원 및 발코니' 에 대한 관리인식정 도가 2.59로 가장 높았으며, 다음으로 '온도조절 및 조명제 어장치(2.45)' 가 높게 나타났다. 이는 관리자가 관리하는 친 환경계획요소의 관리보다는 거주자 자신들이 직접 관리하는
친환경계획요소의 관리가 잘되고 있다고 인식하는 것을 알 수 있게 한다.

3) 관리자가 인식하는 친환경계획요소의 관리실태

관리자가 인식하는 친환경계획요소의 관리실태를 보면< 표 8 참조>, 에너지 및 자원절약부문' 에서는 '쓰레기 분리수 거 및 재활용을 위한 공간' 과 '절수형 설비기기' 가 평균 2.83 으로 가장 잘 관리되고 있다고 인식하는 것으로 나타났 다. '쓰레기 분리수거 및 재활용을 위한 공간' 은 거주자의 인 식정도와 동일한 결과이나, '절수형 설비기기(2.83)' 와 '우수 이용 및 중수도(2.17)' 의 평균이 높은 것은 거주자가 인식하 는 관리실태와 확연히 차이가 남을 알 수 있게 한다. 그 이유 는 거주자들이 절수형 설비기기, 중수도 등에 대한 설비적인 면에 대한 인식이 많이 부족하기 때문이라고 볼 수 있다.

'외부공간 부문' 에서는 '녹지공간' 과 '인공녹화' 가 평균 2.50 으로 다른 계획요소보다 잘 관리되고 있다고 인식하는 것으로 나타났다. 친환경인증아파트에서는 주로 '녹지공간' 에 많은 노력을 기울이기 때문에 거주자와 관리자 모두 녹지 공간이 잘 관리되고 있다고 인식하고 있지만, "실개천 및 분 수 와 '인공녹화' 는 거주자와 관리자의 인식이 크게 다른 것 을 알 수 있다. 은평1지구의 물이 마른 실개천이 거주자에게 는 흥물스러운 존재이지만 관리자는 비용과 설비의 문제로 해결하기 쉽지 않음을 인식하고 있기 때문에 거주자보다 관 리실태 평균이 비교적 높게 나온 것으로 생각할 수 있다. 또 한, 은평뉴타운의 벽면녹화는 아직 활성화되어 있지 않아서 빈공간이 두드러져 보였고, 정릉 현대홈타운 담장에는 비용 문제로 펜스를 설치할 수 없어서 나무로 대강 얼기설기 만들 어 놓은 공간도 있었다. 따라서 직접 실개천과 인공녹화를 관리하는 관리자가 현실적인 문제를 알고 있기 때문에 거주 자보다 관리실태를 높게 평가한 것으로 판단된다.

'건강 및 쾌적성 부문' 에서는 '제어장치(온도조절 및 조 명제어장치)' 가 평균 2.83으로 관리가 잘 되고 있다고 인식 하는 것으로 나타났다.

거주자가 인식하는 친환경계획요소의 관리실태와 비교해 보면, 거주자와 관리자가 모두 건강 및 쾌적성 부문은 대체로 잘 관리되고 있다고 인식하고 있는데, 거주자는 '실내정원 및 발코니'를, 관리자는 '제어장치(온도조절 및 조명제어장 치)' 가 가장 잘 관리되고 있다고 인식하는 것을 알 수 있다. 이는 거주자 자신이 관리하는 실내부분과 관리자가 관리하는 공용부분이 다르기 때문에 나타나는 차이라고 볼 수 있다.

거주자와 관리자가 인식하는 친환경계획요소의 관리실태 를 보면, 음식물쓰레기 감량화·고형화 장치와 수생물공간 항목은 거주자, 관리자 모두 낮게 나타났고 거주자보다 관리 자가 더 낮은 것을 알 수 있다. 현재 은평 1지구 푸르지오 5 
단지에는 음식물쓰레기 감량화 · 고형화 장치가 설치되어 있 는데, 설계의도와는 달리 잘 이용되지 않고 있으며, 이 장치 가 설치되어 있는지 모르는 거주자도 많았다. 또한 종암2차 아이파크의 생태연못에는 생물이 살지 않고, 분수의 물이 작 동되지 않은 채 고여 있어서 거주자들의 불만을 사고 있기 때문에 관리자와 거주자 모두 관리상태가 잘 안되고 있다고 응답한 것으로 판단된다.

\section{3. 아파트 관리특성에 따른 친환경계획요소 관리인식의 차이}

1) 관리유형에 따른 거주자의 인식 차이

관리유형에 따라 거주자가 인식하는 친환경계획요소관리 에 대한 인식의 차이를 알아보기 위하여 거주지역을 은평구 로 한정하여 사업주체관리와 위탁관리로 나누어 $t$-검증을 실시하였다〈표 9 참조〉. 성북구의 경우 모두 위탁관리이기 때문에, 세가지 관리유형이 모두 있는 은평구를 중심으로 비 교하고자 하였으나 자료상의 한계"때문에 사업주체관리와 위탁관리만을 비교하고자한다. 주택법시행령에 따르면 사업 주체관리는 입주초기 입주예정자가 과반수 입주하기 전까지 시공사에 의해 관리되는 방법으로 보통 6 개월 1 년 정도로 볼 수 있다. 이 시기는 친환경건축물인증을 받기 위해 채택 했던 친환경계획요소들의 관리가 비교적 잘되는 기간이라서 위탁관리로 전환된 단지와는 어떤 차이가 있는지를 비교하 는 데 의의를 두었다.

'에너지 및 자원부문' 에서는 쓰레기 분리수거 및 재활용 을 위한 공간 $(P<.001)$ 과 단지 내 자전거 보관소 및 도로 $(P<$ .001), 고효율 에너지 절약형기기 $(P<.05)$ 에 있어서 관리유형 에 따라 통계적으로 유의미한 차이가 나타났다.

외부공간부문에서는 오픈 스페이스 $(P<.001)$, 녹지 공간 $(P<.001)$, 인공녹화 공간 $(P<.01)$, 생태학습원 $(P<.001)$ 이 통계적으로 유의미한 차이가 나타났으며, 건강 및 쾌적성 부 문에서는 실내정원 및 발코니 $(P<.001)$, 온도조절 및 조명제 어장치 $(P<.01)$, 통신 및 생활서비스 $(P<.001)$ 가 통계적으로 유의미한 차이가 나타났다. 결과적으로, 사업주체관리단지 거주자들이 위탁관리단지 거주자들보다 친환경 계획요소의 관리가 더 잘되고 있다고 생각하는 것으로 나타났다. 이는 실제로 사업주체관리가 시행되는 입주 후 1년은 시설보수팀 이 단지내에 상주하는 경우가 많고, 아직 입주 중인 경우가 많기 때문에 관리자들이 초기 아파트단지의 쾌적한 분위기 를 조성하기 위하여 관리에 대해 세심하게 관심을 기울일 가

1) 은평구 자체관리단지 관리자의 허가를 얻지 못하여 거주자들의 인식에 대한 자료를 얻기 어려웠음
〈표 9〉 관리유형에 따른 거주자의 인식 차이

\begin{tabular}{|c|c|c|c|c|}
\hline \multirow[b]{2}{*}{ 부문 } & \multirow[b]{2}{*}{ 항목 } & \multicolumn{2}{|c|}{ 관리유형 } & \multirow[b]{2}{*}{ t값 } \\
\hline & & $\begin{array}{c}\text { 사업주체 } \\
\text { 관리 }\end{array}$ & $\begin{array}{l}\text { 위탁 } \\
\text { 관리 }\end{array}$ & \\
\hline \multirow{8}{*}{$\begin{array}{c}\text { 에너지 } \\
\text { 및 } \\
\text { 자원절약 }\end{array}$} & $\begin{array}{l}\text { 쓰레기 분리수거 및 } \\
\text { 재활용을 위한 공간 }\end{array}$ & 2.97 & 2.39 & $7.38 * * *$ \\
\hline & $\begin{array}{l}\text { 단지 내 자전거 보관소 } \\
\text { 및 도로 }\end{array}$ & 2.93 & 2.20 & $8.80 * * *$ \\
\hline & 에너지절약형 난방설비 & 2.77 & 2.17 & 5.11 \\
\hline & 열 완충 공간 & . & . & . \\
\hline & 고효율 에너지 절약형기기 & 2.63 & 2.01 & $5.11 *$ \\
\hline & 절수형 설비기기 & 2.57 & 1.68 & 6.28 \\
\hline & 우수이용 및 중수도 & 2.37 & 1.46 & 6.42 \\
\hline & $\begin{array}{l}\text { 음식물쓰레기 } \\
\text { 감량화·고형화 장치 }\end{array}$ & & 1.53 & . \\
\hline \multirow{7}{*}{ 외부공간 } & 녹지공간 & 2.93 & 2.46 & $5.88 * * *$ \\
\hline & 오픈스페이스 & 2.97 & 2.26 & $8.62^{* * *}$ \\
\hline & 생태학습원 & 2.93 & 2.17 & $8.79 * * *$ \\
\hline & 인공녹화 & 2.63 & 1.91 & $6.91^{* *}$ \\
\hline & 수생물공간 & . & $\cdot$ & . \\
\hline & 실개천 및 분수 & 2.87 & 1.13 & 23.45 \\
\hline & 공동텃밭 & $\cdot$ & & $\cdot$ \\
\hline \multirow{5}{*}{$\begin{array}{c}\text { 건강 } \\
\text { 및 } \\
\text { 쾌적성 }\end{array}$} & $\begin{array}{l}\text { 실내정원 및 발코니의 } \\
\text { 쾌적성 }\end{array}$ & 2.83 & 2.37 & $4.23^{* * *}$ \\
\hline & 온도조절 및 조명제어장치 & 2.83 & 2.30 & $5.87^{* *}$ \\
\hline & $\begin{array}{l}\text { 통신 및 생활서비스의 } \\
\text { 편리한 이용 }\end{array}$ & 2.87 & 1.80 & $10.05^{* * *}$ \\
\hline & 다양한 휴게공간 조성 & 2.80 & 2.00 & 5.98 \\
\hline & $\begin{array}{l}\text { 거주공간의 환기계획 } \\
\text { (환기시스템) }\end{array}$ & 2.83 & 2.17 & 6.39 \\
\hline
\end{tabular}

주. 3 =잘되고있다, 2 = 보통이다, 1 = 잘 되지 않고 있다 $* p<.05, * * p<.01, * * * p<.001$

능성이 많다. 뿐만 아니라 단지 내 시설의 내용연수도 얼마 되지 않아서 거주자들이 관리가 잘되고 있다고 인식하는 경 향이 있기 때문이라고 사료된다.

2) 입주경과년수에 따른 거주자의 인식 차이

입주경과년수에 따라 거주자의 친환경계획요소 관리에 대한 인식차이를 알아보기 위하여 3년이상과 미만으로 나누 어 $t$-검증을 실시하였다〈표 10 참조〉. 에너지 및 자원부문에 서는 유의미한 차이가 나타나지 않았으나, 입주경과가 3년 미만인 거주자와 3 년 이상인 거주자 모두 쓰레기 분리수거 및 재활용공간이 관리가 잘 되고 있다는 의견은 일치하였다.

외부공간 부문에서는 녹지공간 $(P<.05)$ 과 실개천 및 분수 $(P<.05)$ 가 통계적으로 유의미한 차이가 나타났으며, 입주경 과가 3 년 미만인 거주자들이 3 년 이상인 거주자들보다 녹지 공간과 실개천 및 분수가 잘 관리되고 있다고 생각하는 것을 알 수 있다. 이는 3년 이상 된 친환경인증아파트는 거주자들 
〈표 10〉입주경과년수에 따른 인식차이

\begin{tabular}{|c|c|c|c|c|}
\hline \multirow[t]{2}{*}{ 부문 } & 항목 & \multicolumn{2}{|c|}{$\begin{array}{l}\text { 입주경과년수 } \\
\text { 3년미만3년이상 }\end{array}$} & t값 \\
\hline & $\begin{array}{l}\text { 쓰레기 분리수거 및 } \\
\text { 재활용을 위한 공간 }\end{array}$ & 2.68 & 2.79 & -.71 \\
\hline \multirow{7}{*}{$\begin{array}{c}\text { 에너지 } \\
\text { 및 } \\
\text { 자원절약 }\end{array}$} & $\begin{array}{l}\text { 단지 내 자전거 보관소 } \\
\text { 및 도로 }\end{array}$ & 2.57 & 2.36 & 1.75 \\
\hline & 에너지절약형 난방설비 & 2.33 & 2.11 & 1.78 \\
\hline & 열 완충 공간 & 2.34 & 1.79 & 3.28 \\
\hline & 고효율 에너지 절약형기기 & 2.23 & 2.07 & 1.26 \\
\hline & 절수형 설비기기 & 1.99 & 1.81 & 1.15 \\
\hline & 우수이용 및 중수도 & 1.72 & 1.43 & 1.43 \\
\hline & $\begin{array}{l}\text { 음식물쓰레기 } \\
\text { 감량화·고형화 장치 }\end{array}$ & 1.53 & . & . \\
\hline \multirow{7}{*}{ 외부공간 } & 녹지공간 & 2.56 & 2.32 & $2.03^{*}$ \\
\hline & 오픈스페이스 & 2.48 & 2.50 & -.10 \\
\hline & 생태학습원 & 2.16 & 1.36 & 4.51 \\
\hline & 인공녹화 & 2.21 & 1.82 & 2.30 \\
\hline & 수생물공간 & 1.66 & 1.36 & 1.55 \\
\hline & 실개천 및 분수 & 1.58 & 1.50 & $.54^{*}$ \\
\hline & 공동텃밭 & $\cdot$ & & . \\
\hline \multirow{5}{*}{$\begin{array}{c}\text { 건강 } \\
\text { 및 } \\
\text { 쾌적성 }\end{array}$} & 실내정원 및 발코니의 쾌적성 & 2.60 & 2.50 & 2.00 \\
\hline & 온도조절 및 조명제어장치 & 2.44 & 2.46 & -.19 \\
\hline & $\begin{array}{l}\text { 통신 및 생활서비스의 } \\
\text { 편리한 이용 }\end{array}$ & 2.36 & 2.43 & -.46 \\
\hline & 다양한 휴게공간 조성 & 2.36 & 2.29 & $.57^{*}$ \\
\hline & $\begin{array}{l}\text { 거주공간의 환기계획 } \\
\text { (환기시스템) }\end{array}$ & 2.36 & 2.04 & $2.67^{*}$ \\
\hline
\end{tabular}

주. 3 = 잘되고있다, 2 = 보통이다, 1 = 잘 안되고 있다 $* p<.05, * * p<.01, * * * p<.001$

이 계속 교체되거나 친환경계획요소를 관리하기에 많은 관 리비가 요구되기 때문에 3 년 미만인 단지보다 친환경 계획 요소가 효과적으로 관리되기 어려운 상황인 것으로 보인다. 건강 및 쾌적성 부문에서는 다양한 휴게공간 $(P<.05)$ 과 환기 시스템 $(P<.05)$ 에서 통계적으로 유의미한 차이가 나타났고, 입주경과가 3 년 미만인 단지가 3 년 이상인 단지보다 다양한 휴게공간과 환기시스템의 관리가 더 잘 되고 있다고 생각하 는 것으로 나타났다.

\section{4. 효율적인 친환경계획요소 관리를 위해 필요한 요소}

'친환경인증아파트의 효율적인 친환경계획요소 관리를 위해 필요한 요소' 에 대해 거주자들의 응답을 통하여 분석한 결과〈그림 4참조〉, 관리자의 능력이 중요하다고 생각하는 의견이 응답자 199 명 중 85(42.7\%)명으로 가장 높았고, 다음 으로 거주자의 인식개선이 중요하다고 생각하는 것으로 나 타났다. 이는 거주자들이 친환경계획요소를 효율적으로 관 리하기 위해서 현실적인 비용이나 기술적인 문제보다는 물

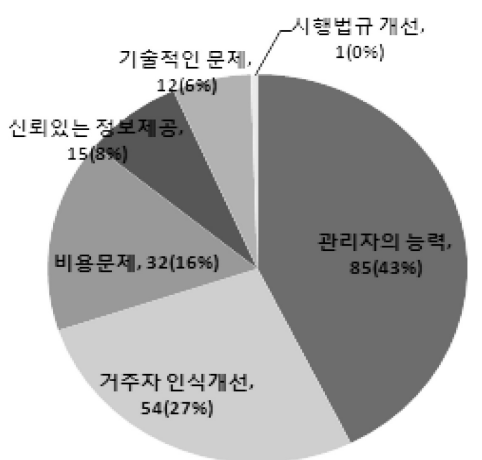

〈그림 4〉효율적인 친환경계획요소 관리를 위해 필요한 요소 (거주자)

리적인 요소를 직접 사용하고 관리하는 사람들의 생각이나 인식을 더 중요하다고 생각하는 것을 알 수 있다.

반면, 관리자들에게 개방형 질문을 통해 알아본 결과 6 개 단지 모두 '거주자의 인식개선' 을 효율적인 친환경계획요소 관리를 위해 가장 필요한 요소로 보았다. 이는 비용보다는 사 람의 인식이 중요하다는 것으로서 인식개선이 중요하다는 것 은 일치하나 관리자의 능력을 우선시 하는 거주자들과는 다 른 의견인 것을 알 수 있다. 이와 같은 것은 입주자에 대해서 도 입주전 홍보와 입주후 교육 등 친환경계획요소 사용에 대 한 주의 깊은 사후관리의 중요성을 말해주고 있고, 관리자의 측면에서도 관리의 지속성을 위해 어떻게 대처해야하는가 하 는 기술적 측면에 대한 이해와 더불어 관리방법에 대해 끊임 없이 연구하고 실천할 수 있는 능력이 필요함을 알 수 있게 한다. 이처럼 친환경계획요소들이 미래지향적인 측면에서 주 거환경수준의 개선에 기여하고 있는 측면도 많지만, 거주자 와 관리자가 함께 협력하지 않는다면 이용과 관리측면에서는 시행사와 건설사의 홍보효과에 그치고 오히려 입주자와 관리 자의 불만요소가 될 개연성을 충분히 보여주고 있다.

\section{IV. 결 론}

본 연구에서는 친환경건축물인증아파트의 건설시 계획목 표에 따라 실제로 적용된 친환경계획요소의 관리실태를 살 펴보고자 하였다. 우선, 친환경건축물인증제도의 심사기준 을 고찰하고, 심사기준에 나타나는 계획목표를 3가지 측면으 로 요약하여 그에 따라 실제로 적용되는 친환경계획요소를 추출하여 평가도구를 만들었다. 이러한 평가도구를 가지고 관리자와 거주자를 대상으로 친환경계획요소들에 대한 관리 실태, 거주자의 친환경계획요소의 이용실태, 아파트 관리 특 성에 따라 관리자와 거주자의 친환경계획요소 관리를 위해 필요한 요소를 조사 분석하였다. 
먼저, 거주자와 관리자가 인식하는 친환경계획요소의 관 리실태를 계획목표에 따라 3 개 부문, 20 개 항목으로 살펴보 았다. 관리자와 거주자가 쓰레기 분리수거 및 재활용을 위한 공간이나 녹지공간이 관리가 잘 되고 있다고 인식하는 등 동 일한 결과를 보이기도 하였으나, 설비적인 부분에서는 인식 이 부족하여 관리 상태를 판단하기 어려운 것으로 나타났다. 그리고 친환경계획요소가 설치는 되어있으나 여러 가지 여 건이 맞지 않아 관리가 어렵거나 거주자가 제대로 활용하지 못하는 문제가 발생하는 것으로 나타났다. 이는 가시적인 친 환경요소를 중심으로 도입하고 그것을 이용하거나 관리해야 하는 사람들의 상황을 고려하지 않았기 때문에 발생한 것으 로 볼 수 있다. 따라서, 현재의 친환경건축물인증아파트의 현황에 대해서 면밀히 살펴보고 설계자, 관리자, 거주자 모 두가 공감할 수 있는 친환경계획요소를 도입한 단지를 설계 해야하며, 이의 지속적인 관리를 위한 부가적 장치가 마련되 어야 할 것으로 보인다. 관리유형과 입주경과년수에 따른 차 이를 분석한 결과 입주기간이 1년 미만인 사업주체관리 단지 의 관리가 더 잘되고 있다고 나타났다. 그 이유는 입주경과 년수가 길어질수록 거주자들이 교체되고 시설도 노후화되면 서 비용적인 문제가 발생하고, 관리자와 거주자간의 커뮤니 케이션이 원활하게 이루이지지 않는다는 문제가 발생하기 때문이다. 그러므로 무엇보다도 관리자는 비용 및 기술적인 문제와 같은 물리적인 요소와 거주자들의 생각과 인식을 함 께 고려해야 하며, 거주자는 자신이 사는 아파트에 대해서 관심을 갖고 참여를 하는 것이 친환경계획요소들이 계획대 로 이용되고 관리상태가 양호하게 지속될 수 있는 주요한 요 인으로 작용할 것으로 보인다.

현 상황에서 친환경건축물인증아파트의 관리적인 측면을 봤을 때, 거주자와 관리자 모두 친환경건축물인증제도나 그 심사기준에 맞추어 단지별로 도입되는 친환경계획요소에 대 해 제대로 알지 못하고 관심이 많이 부족한 상황이라고 볼 수 있다. 거주자 인터뷰결과 현재 친환경인증아파트에 거주 하고 있는지 조차 인식하지 못하고 있눈 경우도 있었다. 따 라서 각 친환경건축물인증아파트에 적용된 친환경계획요소 가 효율적으로 관리되기 위해서는 먼저 해당단지의 친환경 계획요소의 특성을 입주 시 거주자에게 교육을 하고 인식개 선을 유도하는 것이 바람직할 것이다. 뿐만 아니라 친환경계 획요소 관리활동에 참여하면 관리비에 인센티브를 부여하는 방안 등 보상계획이 함께 마련된다면 더 높은 거주자 참여를 유도할 수 있을 것이다.

또한 관리자에게도 친환경건축물인증아파트의 친환경계 획요소 관리에 대한 체계적인 교육을 통해 전문적인 지식을 가질 수 있도록 도와야 하며, 관리의 중요성을 인식하고 거 주자를 유도하여 이용 및 활용도를 높일 수 있는 저력이 있
는 사람을 채용할 필요가 있다. 설계단계에서도 확실한 현장 조사, 거주자의 사용 및 활용방식, 관리자의 관리방식에 대 한 이해를 바탕으로 즉, 지속적 활용과 관리를 염두에 두고 친환경건축물인증을 받기 위해 어떠한 친환경계획요소를 어 떻게 적용할 것인지 신중하게 검토 후 설계 및 시공을 해야 할 것이다.

이미 친환경건축물 본 인증을 받은 아파트의 친환경계획 요소의 관리상태를 양호하게 유지하기 위해서는 인증단체에 서도 지속적으로 인증받은 단지들을 정기적으로 재점검하여 재인증 및 인증 취소 등의 운영기법을 활용하여 지속적인 친 환경계획요소 관리를 위한 정책적 뒷받침을 구상해야할 것 이다. 또한, 이처럼 친환경건축물인증 등의 제도가 시행되는 이유는 거주자의 지속가능한 삶을 위한 것이므로 앞으로 인 증기관에서도 관리지속성을 염두에 둔 인증기준 재정비 등 의 노력이 필요할 것이다.

\section{참고문헌}

강미란(2004). 환경친화형 주거단지를 위한 인센티브 적용에 관한 연구. 단국대학교 대학원 석사학위논문.

국토해양부, 환경부(2006). 친환경건축물인증제도 세부시행

지침. 과천: 국토해양부, 환경부.

국토해양부(2009a). 2009년도 주택업무편람. 과천: 국토해양부. 국토해양부(2009b). 친환경건축물 인증심사 기준 개선 및 인증제도 활성화 방안 연구. 과천: 국토해양부.

권성실, 오덕성, 김경배(2006), 지속가능한 정주지 계획요소 의 중요도 분석. 서울도시연구, 7(3), 1-14.

권오진(2004). 아파트 단위주거의 친환경적 계획요소에 관한 실

무자 의식조사. 연세대학교 대학원 석사학위논문.

김선숙, 양인호, 김광우(2002). 공동주택 거주성능 평가에

관한 연구. 한국생활환경학회지, 9(2), 154-159.

류지원(2004). 공동주택 환경친화 계획요소에 관한연구. 계 명대학교 대학원 박사학위논문.

박영기(1990). 공동주택의 주거환경에 대한 거주 후 평가 연

구. 대한건축학회 논문집, 6(1), 41-48.

소경용(2008). 아파트 브랜드화에 따른 주택시장영향에 관한

연구. 건국대학교 부동산대학원 석사학위논문.

신영숙, 조명은(2006). 친환경아파트 단지 거주자들의 친환 경계획요소에 대한 인식에 관한 연구. 대한건축학회논

문집, 22(8), 135-145.

유성정(2007). 친환경건축물인증지표와 거주만족도의 비교 분석 연구. 서울시립대학교 도시과학대학원 석사학위 논문. 
유은미(2008). 친환경건축물인증 아파트단지 거주자의 주거 환경 만족도: 울산 S 아파트를 중심으로. 건국대학교 교육대학원 석사학위논문.

윤수진(2009). 친환경건축물 공동주택단지 내 비오톱 조성의 문제점 및 개선방향에 관한 연구. 서울대학교 환경대 학원 석사학위논문.

이도형(2003). 친환경공동주택의 특성분석 및 인식에 관한 연구 : 친환경건축물인증제도(공동주택)을 중심으로. 창원대학교 대학원 석사학원논문.

이지영(2005). 거주자의 생태적 환경 및 친환경 주거계획요 소 인식연구. 연세대학교 대학원 석사학위논문.

임승남(2006). 주거단지 친환경계획요소에 대한 만족도 및 중요도 평가에 관한 연구. 한양대학교 도시대학원 박 사학위논문.

정선모(2005). 사례분석을 통해 본 한국의 집합주거단지 계 획에서의 친환경적 문제점에 관한연구. 단국대학교 대
학원 석사학위논문.

정희석, 정동훈, 제해성(2009). 초고층 주거복합건축물 옥외 공간의 친환경계획요소에 관한 연구. 대한건축학회 학

술발표대회 논문집, 29(1), 145-148.

최영현(2006). 도시근교형 전원주택단지의 친환경적 계획특 성 분석. 충남대학교 대학원 석사학위논문.

최유리(2007). 브랜드아파트에 적용된 친환경적 계획요소에 관한연구. 한양대학교 대학원 석사학위논문.

최윤아, 송병하(2007). 공동주택 주거환경 계획요소 및 친환 경계획요소의 특성 및 경향분석에 관한 연구, 대한건

축학회논문집, 23(1), 109-118.

환경부(2009). 저탄소 녹색성장 추진방안. 과천: 환경부.

접 수 일 : 2010년 8월 31일

심사시작일 : 2010년 9월 7일

게재확정일 : 2010년 10월 27일 